(c) American Dairy Science Association, 2003.

\title{
Effect of Lactobacillus helveticus and Propionibacterium freudenrichii ssp. shermanii Combinations on Propensity for Split Defect in Swiss Cheese ${ }^{1}$
}

\author{
S. R. White, ${ }^{\star 2}$ J. R. Broadbent, ${ }^{*}$ C. J. Oberg, $†$ and D. J. McMahon ${ }^{\star}$ \\ *Western Dairy Center \\ Department of Nutrition and Food Sciences \\ Utah State University, Logan 84322-8700 \\ †Department of Microbiology \\ Weber State University, Ogden, UT 84408-2506
}

\begin{abstract}
One of the least controlled defects in Swiss cheese is development of splits that appear during refrigerated storage after cheese is removed from the warm room. Such fissures, or cracks, in the body of the cheese can be as short as $1 \mathrm{~cm}$, or long enough to span a $90-\mathrm{kg}$ block. A $2 \times 2 \times 2$ factorial experiment was used to determine the effect of different Lactobacillus helveticus/Propionibacterium freudenreichii ssp. shermanii starter culture combinations on the occurrence of split defect in Swiss cheese. Eights vats of cheese were made in summer and eight in winter. Each 90-kg block of cheese was cut into twenty-four $4-\mathrm{kg}$ blocks and graded based on the presence of splits.

Only small variations were found in the composition of cheeses made during the same season. There were no correlations between moisture, $\mathrm{pH}$, fat, protein, calcium, lactose contents, D/L lactate ratio, or protein degradation that could be used to predict splits after $90 \mathrm{~d}$ of storage. However, cheese made in the summer had $2 \%$ higher moisture content and a greater prevalence of splits. There was a sixfold increase in amount of downgraded cheese between the best and worst culture combinations used during cheese manufacture. After 90-d storage, 14 to $90 \%$ of cheese had splits in the summer, and 1 to $6 \%$ in the winter. Split formation increased with time from 60 to $120 \mathrm{~d}$ of storage and extent of split formation was influenced by both the lactobacilli and propionibacteria cultures used.

(Key words: nonstarter, lactic acid bacteria, moisture, crack)
\end{abstract}

\footnotetext{
Received May 6, 2002.

Accepted June 25, 2002.

Corresponding author: Donald J. McMahon; e-mail: djm@ cc.usu.edu.

${ }^{1}$ Contribution number 7470 of the Utah Agricultural Experiment Station. Approved by the director.

${ }^{2}$ Current address: Brewster Dairy Inc., 675 Wabash Ave. S., Brewster, $\mathrm{OH} 44613$.
}

\begin{abstract}
Abbreviation key: L1, L2 = strains of L. helveticus starter culture used, $\mathbf{P 1}, \mathbf{P 2}=$ strains of $P$. freudenreichii ssp. shermanii starter culture used.
\end{abstract}

\section{INTRODUCTION}

One of the most common defects in Swiss cheese is the development of splits characterized by fissures or cracks in the body of the cheese that can be as short as $1 \mathrm{~cm}$ in length or long enough to span a $90-\mathrm{kg}$ block. Split defect typically appears during refrigerated storage after the eyes have fully developed and the cheese is moved from the warm room. Once the cheese is cold, it has a firmer body and further gas production causes the cheese to fracture and form splits (Hettinga et al., 1974; Langsrud and Reinhold, 1974). Splits in Swiss cheese make the cheese unsuitable for use on high speed slicing equipment (operating at up to 1000 slices per minute). The presence of splits in Swiss cheese can result in the cheese being downgraded with a subsequent loss to the manufacturer of about 20 cents per kilogram (Skrzycki, 2000).

In the manufacture of Swiss cheese, two major bacterial fermentations occur. The first is the conversion of lactose to lactic acid by lactic acid bacteria during the early stages of manufacture (from coagulum set to brining or pre-cooling). Streptococcus thermophilus and Lactobacillus helveticus are the most common combination of lactic acid bacteria starters used in Swiss cheese production. The $S$. thermophilus culture serves as the initial and primary lactic acid producer (Steffen et al., 1993). The L. helveticus culture acts as a secondary acid-producer to help control cheese $\mathrm{pH}$, as well as causing proteolysis in the later stages of ripening and contributing to formation of specific flavor compounds (Palma et al., 1987). Under normal vat conditions, D and/or L-lactic acid are essentially the only end-products of lactose fermentation from the time the starter is added until 18 to $24 \mathrm{~h}$ later before brining (Salminen and Wright, 1998). 
The second major bacterial fermentation during Swiss cheese manufacture is the conversion of $\mathrm{D}$ and L-lactate to propionate, acetate, and $\mathrm{CO}_{2}$ by propionibacteria during cheese storage in the warm room (at 20 to $25^{\circ} \mathrm{C}$ ) (Steffen et al., 1993). In Swiss-type cheese, Propionibacterium freudenreichii is the most widely used species of propionibacteria (Gautier et al., 1995), and it will utilize L-lactate preferentially over D-lactate because L-lactate metabolism results in the production of a high intracellular pyruvate concentration, which has a strong inhibitory effect on D-lactate dehydrogenase activity (Langsrud and Reinbold, 1973; Pivateau et al., 1995; Thierry et al., 1999). Propionic acid contributes to the flavor of Swiss cheese, while the carbon dioxide produced is responsible for eye formation.

A pliable curd mass is necessary for development of round eyes rather than slits or cracks. For example, an elastic protein network bends or gives as carbon dioxide accumulates, but does not break, forming an eye. On the other hand, if the protein network is too rigid, it cannot withstand the pressure, and a split (or slit) will form. Pliability (elasticity) of cheese is a function of protein density, temperature, and cheese physiochemistry (Johnson, 2001; Mocquot, 1979). Hydration of the casein molecules, calcium-phosphate bonding, and electrostatic and hydrophobic interactions between casein molecules can all influence cheese elasticity. Thus, acid development during cheese making must be tightly controlled as cheese physiochemistry has potentially more impact on suitability of the cheese for eye formation than does proteolysis.

The temperature at which cheese is stored affects growth of the propionibacteria as well as the elasticity of the protein network. The warmer the cheese, the more elastic the protein. The rate of gas development is also critical for eye formation. If gas develops too rapidly, the casein network may not be able to yield to the increased gas pressure and splits will form. If gas forms too slowly, the cheese may become underset, resulting in small eyes or blind cheese (no eyes). Problems can also occur if cheese makers leave cheese in the warm room too long, resulting in over-set cheese (large eyes).

Formation of splits has been attributed to a wide variety of causes and interactions. These include: starter or nonstarter propionibacteria that produce gas at the cold room temperatures of 4 to $7^{\circ} \mathrm{C}$ (Park et al., 1967; Hettinga et al., 1974), cheese elasticity in relation to proteolysis (Johnson, 2001), starter or nonstarter lactic acid bacteria metabolite stimulation of propionibacteria (Thierry et al., 1999), and the presence and germination of Clostridium tyrobutyricum spores (Dasgupta and Hull, 1989; Steffen et al., 1993). Low quality silage (e.g., silage with high spore count and high $\mathrm{pH}$ ) used during winter is the most probable source of clostridial contamination in milk.

Thus, split defect in Swiss cheese may be caused by any one, or a combination of, the causes noted above. The objectives of this study were to determine whether different combinations of $L$. helveticus and $P$. freudenreichii ssp. shermanii starter bacteria have an effect on the number of splits appearing in Swiss cheese after 60 and $90 \mathrm{~d}$ of storage. In addition, we wanted to determine whether there are differences between split and normal cheeses with regards to cheese physiochemistry (moisture, fat, protein, calcium D/L lactate, lactose, proteolytic breakdown during storage) and cheese microbiology (changes in cheese starter and nonstarter bacteria populations in cheese during storage) that could be used to predict the likelihood of split formation during cheese storage.

\section{MATERIALS AND METHODS}

\section{Cultures}

Direct set cultures, suitable for Swiss cheese manufacture, of $L$. helveticus (designated $\mathbf{L 1}$ and L2), $P$. freudenreichii ssp. shermanii (designated P1 and P2), and $S$. thermophilus were obtained from DSM Food Specialties USA Inc. (Millville, UT). Acid production rates for the lactobacilli strains L1 and L2 were the same, and proteolytic activities were similar with $o$ phthaldialdehyde test (Oberg et al., 1991) values of 0.94 and 1.04, respectively.

\section{Cheese Manufacture}

Cheese was manufactured by a commercial cheese manufacturer using the traditional rindless block procedure as described by Reinbold (1972). Milk was standardized to $3 \%$ fat, heat-treated and $5400 \mathrm{~kg}$ of milk at $34^{\circ} \mathrm{C}$ was pumped into each double-O cheese vat (Damrow DEC International, Fond du Lac, WI). The culture combinations (L1P1, L1P2, L2P1, L2P2), plus $S$. thermophilus starter were added at inoculum levels based on the manufacturer's recommendation as the milk was pumped into the vats. Inoculated milk was ripened for $45 \mathrm{~min}$ and then set with $285 \mathrm{ml}$ of Sure Curd (Cryphonectria parasitica) coagulant (Pfizer, Inc., Milwaukee, WI) diluted in $2 \mathrm{~L}$ of water. After 30 $\mathrm{min}$, the curd was cut and allowed to heal for $40 \mathrm{~min}$. The curd was cooked to $49^{\circ} \mathrm{C}$ over 30 min then held at $49^{\circ} \mathrm{C}$ for approximately $45 \mathrm{~min}$. The whey and curd were pumped to the universal vats, then whey was drained and the curd was pressed for $18 \mathrm{~h}$. The cheese was cut into five 90-kg blocks per universal, brined 
for 24, then air-dried and vacuum packed, and placed in a $4^{\circ} \mathrm{C}$ precool room. On $\mathrm{d} 7$, the blocks were placed in a $21^{\circ} \mathrm{C}$ warm room for eye development. After approximately $21 \mathrm{~d}$ in the warm room, the cheeses were examined, and if eye development was adequate, the cheese was transferred to cold storage $\left(4^{\circ} \mathrm{C}\right)$. Ripening time in the warm room ranged from 24 to $30 \mathrm{~d}$. Each $90-\mathrm{kg}$ block of cheese was then cut into $4-\mathrm{kg}$ "retail" blocks. These 4-kg blocks were inspected as they passed along the cutting line and graded according to company procedures as being either "A" grade if no splitting (or insignificant splitting) was present or downgraded to " $\mathrm{C}$ " grade if the cheese blocks contained splits.

\section{Sampling}

Cheese was sampled at $\mathrm{d} 1$ (before brine), 7 (before warm room), d 28 (before finishing-cooler), d 60, 90, and 120. Microbial analysis was conducted at each sampling point; $\mathrm{pH}$ was measured on $\mathrm{d} 1,7$ and 28 , whereas the remaining samples were frozen and stored for chemical analysis. Fat, protein, moisture, calcium, D/L lactate ratios, and lactose were determined from $d-1$ samples.

\section{Cheese Composition}

Cheese $\mathrm{pH}$ was measured using the gold electrode/ quinhydrone method (Marshall, 1992). Moisture, fat, and protein were determined using near infrared light absorption (Instalab 600 NIR Product Analyzer, Dicky-John, Auburn, IL). Calcium was determined using inductively coupled plasma atomic emission spectroscopy. Lactic acid isomers $\mathrm{D}$ and $\mathrm{L}$ were determined enzymically (cat. no. 1128211, Boehringer Mannheim, Indianapolis, IN). Residual sugar (lactose and galactose) was determined enzymically (cat. no. 176303, Boehringer Mannheim, Indianapolis, IN).

\section{Proteolysis}

Proteolysis was measured using capillary electrophoresis (PACE 2100 system, Beckman Instruments, Inc., Fullerton, CA) according to the method of Strickland et al. (2001). Peak areas were used for calculating the extent of hydrolysis of intact $\alpha_{\mathrm{s} 1}$-casein and $\beta$ casein. The water-soluble peptide fraction of casein hydrolysis was determined with $12 \%$ TCA-soluble nitrogen as described by Butikofer et al. (1993) and Polychroniadou et al. (1999).

\section{Microbiological Analysis}

Esculin cellobiose agar was used to differentiate Lactobacillus, Pediococcus, and Streptococcus species at $1,7,28,60$, and $90 \mathrm{~d}$, based on colony morphology, color, and diameter according to the method of Hunger (1986). Plates were incubated anaerobically at $40^{\circ} \mathrm{C}$ for $48 \mathrm{~h}$ in gas pack jars. Duplicates of like colonies from d-7 sampling were isolated and analyzed using the API 50 identification method (BioMerieux, Lombard, IL) for presumptive species classification. Enumeration of total lactic acid bacteria was determined by the pour plate method with MRS agar (DeMan et al., 1960). Enumeration of streptococci in cheeses made during the winter was performed using M-17 agar (Terzaghi and Sandine, 1975).

\section{Statistical Analysis}

The data were analyzed as a $2 \times 2 \times 2$ factorial with two seasons (summer, winter) and four treatments incorporating two L. helveticus and two $P$. freudenreichii ssp. shermanii cultures in duplicate for each season. Statistical analysis (PROC MIXED) was performed using SAS version 8 (SAS Inst., Inc., Cary, NC). Contrasts were used for d-90 data in order to overcome the effects of missing winter L2P2-treatment combination cheeses. Covariance analysis was applied to account for any differences in composition during manufacture. Means were compared using differences of least squares means with Tukey-Kramer honest significant difference adjustments. Pearson correlation coefficients (PROC CORR) were obtained to investigate possible linear correlations between the grade of the cheese at $90 \mathrm{~d}$ and the compositional or proteolytic profiles of the treatments. Significance was declared at $P \leq 0.05$.

\section{RESULTS AND DISCUSSION}

\section{Cheese Composition}

The target $\mathrm{pH}$ for the cheese was $5.15 \pm 0.05$ at 18 $\mathrm{h}$ after culture addition and this target was achieved for cheeses made during both seasons (Table 1). During storage, the summer cheese rose in $\mathrm{pH}$ more than the winter cheese. The mean $\mathrm{pH}$ at $\mathrm{d} 28$ was 5.41 for summer cheese and 5.30 for winter cheese. Only small variations were found in the composition of cheeses made during the same season (Table 2). Moisture content was in the range 37.0 to $37.9 \%$ for summer cheese, and 35.0 to $35.5 \%$ for winter cheese. This was significantly different even though the make procedure was identical for both seasons, and was probably related to seasonal differences in milk composition. There was also a $2 \%$ difference in fat content between summer and winter cheese resulting from lower moisture in the winter cheese and milk standardization being based on fat content rather than casein-to-fat ratio. 
Table 1. $\mathrm{pH}$ values for Swiss cheese made during winter and summer using Lactobacillus helveticus (L1, L2) and Propionibacterium freudenreichi ssp. shermanii (P1, P2) culture combinations at $18 \mathrm{~h}, 7 \mathrm{~d}$, and $28 \mathrm{~d}$ of storage.

\begin{tabular}{lccc}
\hline & \multicolumn{3}{c}{$\mathrm{pH}$} \\
\cline { 2 - 4 } Cheese & $18 \mathrm{~h}$ & $7 \mathrm{~d}$ & $28 \mathrm{~d}$ \\
\hline Summer & & & \\
L1P1 & 5.14 & 5.31 & 5.45 \\
L1P2 & 5.14 & 5.25 & 5.42 \\
L2P1 & 5.19 & 5.30 & 5.38 \\
L2P2 & 5.15 & 5.28 & 5.39 \\
Winter & & & \\
L1P1 & 5.16 & 5.23 & 5.30 \\
L1P2 & 5.14 & 5.26 & 5.31 \\
L2P1 & 5.10 & 5.20 & 5.28 \\
L2P2 & 5.10 & 5.25 & 5.32 \\
\hline
\end{tabular}

There were no significant variations in other chemical parameters for which the cheese was analyzed. Mean calcium content of the cheeses was $0.96 \pm 0.02 \%$. Lactose contents of the cheeses were $0.03 \%$. the mean D/L-lactate ratio was $0.18 \pm 0.03$.

\section{Proteolysis}

Examples of capillary electropherograms of Swiss cheese at 1, 7, 28, and $90 \mathrm{~d}$ are shown in Figure 1. Clear separation of peaks was obtained and peaks corresponding to $\alpha_{\mathrm{s} 1}$-casein and $\beta$-casein (A1 and A2), $\alpha_{\mathrm{s} 1}$-casein (f 1-23), and $\alpha_{\mathrm{s} 1}$-casein (f 24-199) were identified by coelution with pure standards. Presumptive identification of other peaks in the electropherograms were made for $\alpha_{\mathrm{s} 1}$-casein $9 \mathrm{P}$ and $\beta$-casein $\mathrm{B}$ based on Reicio et al. (1997) and Otte et al. (1999). Only the $\alpha_{\mathrm{s} 1}$-casein and $\beta$-casein (A1 and A2) peaks were included in calculations for protein hydrolysis. Similar proteolysis patterns were observed for all of the cheeses. The amounts of intact $\alpha_{\mathrm{s} 1^{-}}$and $\beta$-casein

Table 2. Mean composition of cheeses for each treatment within season.

\begin{tabular}{llll}
\hline Cheese & Moisture & Fat & Protein \\
\cline { 2 - 2 } & & & \\
\cline { 2 - 4 } Summer & & & \\
L1P1 & $37.9^{\mathrm{a}}$ & $32.0^{\mathrm{c}}$ & $26.1^{\mathrm{ab}}$ \\
L1P2 & $37.4^{\mathrm{ab}}$ & $32.8^{\mathrm{bc}}$ & $26.4^{\mathrm{ab}}$ \\
L2P1 & $37.0^{\mathrm{b}}$ & $33.5^{\mathrm{b}}$ & $26.3^{\mathrm{ab}}$ \\
L2P2 & $37.1^{\mathrm{b}}$ & $32.9^{\mathrm{bc}}$ & $26.5^{\mathrm{ab}}$ \\
Winter & & & \\
L1P1 & $35.5^{\mathrm{c}}$ & $34.6^{\mathrm{ab}}$ & $27.2^{\mathrm{a}}$ \\
L1P2 & $35.2^{\mathrm{c}}$ & $34.9^{\mathrm{a}}$ & $26.0^{\mathrm{b}}$ \\
L2P1 & $35.0^{\mathrm{c}}$ & $35.0^{\mathrm{a}}$ & $26.7^{\mathrm{ab}}$ \\
L2P2 & $35.5^{\mathrm{c}}$ & $34.6^{\mathrm{ab}}$ & $26.7^{\mathrm{ab}}$ \\
\hline
\end{tabular}

a,b,c Means within same column with no common superscript differ $(P<0.05)$.

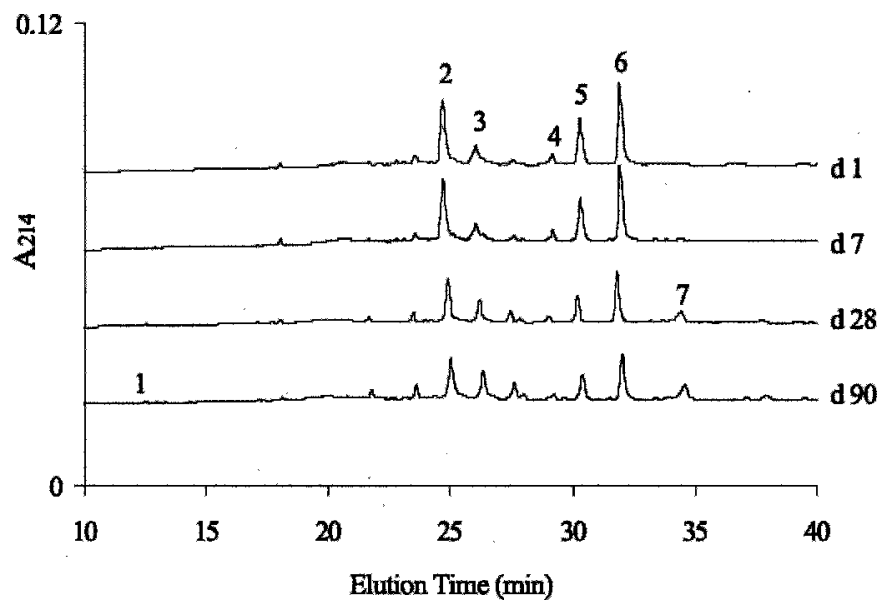

Figure 1. Capillary electropherogram of milk proteins during ripening in summer Swiss cheese made using L1P2 culture combination. Migration of intact proteins and hydrolysis products is indicated by the following numbers: (1) $\alpha_{\mathrm{s} 1}$-casein (f 1-23), (2) $\alpha_{\mathrm{s} 1}$-casein, (3) $\alpha_{\mathrm{s} 1^{-}}$ casein 9P, (4) $\beta$-casein $\mathrm{B}$, (5) $\beta$-casein $\mathrm{A} 1,(6) \beta$-casein $\mathrm{A} 2$, and (7) $\alpha_{\mathrm{s} 1^{-}}$ casein (f 24-199).

decreased at a similar rate over time in all of the cheeses (Figure 2), and formation of $\alpha_{\mathrm{s} 1}$-casein (f 24199) was apparent by $d 28$. There was more overall degradation of $\alpha_{\mathrm{s} 1}$-casein and $\beta$-casein in the cheeses made during the summer than cheese made in the winter. This difference was probably because of higher moisture levels in the summer cheeses.

Significant sources of variation for intact $\alpha_{\mathrm{s} 1}$-casein content were season, storage time, and the two-way interactions of season $\times$ culture, and season $\times$ time (Table 3). As expected, culture had no significant effect on hydrolysis of intact caseins during storage of the cheese. The only significant source of variation for intact $\alpha_{\mathrm{s} 1}$-casein, when each sampling time was analyzed individually, was season at $\mathrm{d} 60$. However, there was no correlation between extent of $\alpha_{\mathrm{s} 1}$-casein hydrolysis and prevalence of splits.

It was estimated that $14 \%$ of the intact $\alpha_{\mathrm{s} 1}$-casein had been hydrolyzed in the summer cheeses, whereas only $10 \%$ had been hydrolyzed in the winter cheeses between $d 1$ (before brine) and $d$ (before warm room) (Figures 3 and 4). In this time period, the temperature of the brine and cold room was $4^{\circ} \mathrm{C}$. From 7 to $28 \mathrm{~d}$, the cheese was cured in the warm room at $21^{\circ} \mathrm{C}$, and a further $30 \%$ of intact $\alpha_{\mathrm{s} 1}$-casein was hydrolyzed during this period, for both winter and summer. It was estimated that another 30 to $35 \%$ of the intact $\alpha_{\mathrm{s} 1}$-casein had been hydrolyzed during the 28 to 60 -d storage period in the cold room $\left(4^{\circ} \mathrm{C}\right)$ for both season's cheeses.

Significant sources of variation for residual levels of intact $\beta$-casein were season and storage time, and 
Table 3. ANOVA probabilities of factors that may affect the concentration of intact $\alpha_{\mathrm{s} 1}$-casein and $\beta$-casein (A1 and A2) remaining in cheese as a function of season, culture, and time.

\begin{tabular}{llll}
\hline & \multicolumn{2}{c}{$P$} \\
\cline { 2 - 4 } Source of variation & $\alpha_{\mathrm{s} 1}$-casein & $\beta$-casein A1 & $\beta$-casein A2 \\
\hline Season & $\mathbf{0 . 0 0 3}$ & 0.421 & $\mathbf{0 . 0 1 6}$ \\
Culture & 0.522 & 0.617 & 0.328 \\
Time & $\mathbf{0 . 0 0 1}$ & $\mathbf{0 . 0 0 1}$ & $\mathbf{0 . 0 0 1}$ \\
Season $\times$ culture & $\mathbf{0 . 0 3 2}$ & 0.218 & 0.810 \\
Season $\times$ time & $\mathbf{0 . 0 0 4}$ & $\mathbf{0 . 0 3 2}$ & 0.688 \\
Culture $\times$ time & 0.366 & 0.529 & 0.994 \\
Season $\times$ culture $\times$ time & 0.325 & 0.059 & 0.917 \\
\hline
\end{tabular}

the two-way interactions of season $\times$ time (Table 3). When analysis of variance was conducted separately for each storage time, the only significant source of variation was season for $\beta$-casein $\mathrm{A} 2$ at $60 \mathrm{~d}$, and the two-way interaction of season $\times$ culture at $90 \mathrm{~d}$ for $\beta$ casein A1. There was, however, no evidence to suggest a relationship between $\beta$-casein hydrolysis and prevalence of splits.

It was estimated that from $d 1$ (before brine) until d 7 (before warm room), 16\% of the intact $\beta$-casein had been hydrolyzed in the summer cheeses, and $10 \%$ in the winter cheeses. An additional 34 and $28 \%$ of $\beta$ -
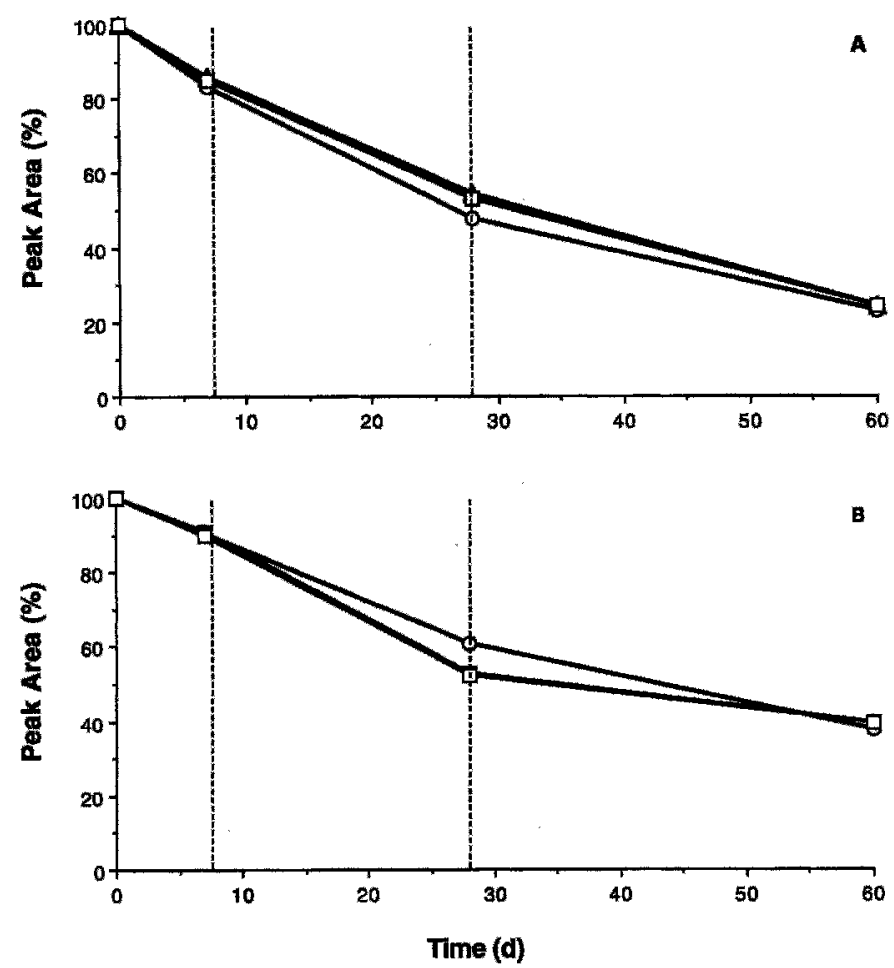

Figure 2. Disappearance of intact $\alpha_{\mathrm{s} 1}$-casein $(\triangle), \beta$-casein $\mathrm{A} 1(\bigcirc)$, $\beta$-casein A2 ( $\square$ ) in Swiss cheese made from summer milk (A) and winter milk (B). Dotted lines represent the time the cheese was held in the warm room at $21^{\circ} \mathrm{C}$. casein was hydrolyzed in the summer cheeses during d 7 to $d 28$ of warm room storage for summer and winter cheeses, respectively. Proteolysis continued from d 28 to d 60 of storage in the cold room $\left(4^{\circ} \mathrm{C}\right)$ with an additional 27 and $13 \%$ of intact $\beta$-casein being hydrolyzed in the summer and winter cheeses. Bastian et al. (1997) showed similar rates of $\beta$-casein degradation with $43 \%$ of intact $\beta$-casein being hydrolyzed over a 42 -d ripening period.

In cheeses, such as Cheddar and Mozzarella, that use chymosin as the coagulant and have a lower curd/ whey cooking temperature, the breakdown of $\alpha_{\mathrm{s} 1}$-casein occurs more rapidly than does that of $\beta$-casein (Strickland et al., 2001; Dave et al., 2003). Swiss cheese had earlier been described as an alpha-ripening cheese in which the $\alpha_{\mathrm{s} 1}$-casein peak had the greatest rate of disappearance in comparison to $\beta$-casein (Langsrud and Reinbold, 1973). Other research on $\alpha_{\mathrm{s} 1}$ casein degradation in Swiss cheese has shown high concentrations of intact $\alpha_{\mathrm{s} 1}$-casein remaining after manufacture (Steffen et al., 1993; Fox and McSweeny, 1996), presumably because of inactivation of coagulant during the high cook temperature used in Swiss cheese manufacture. It has been suggested that be-

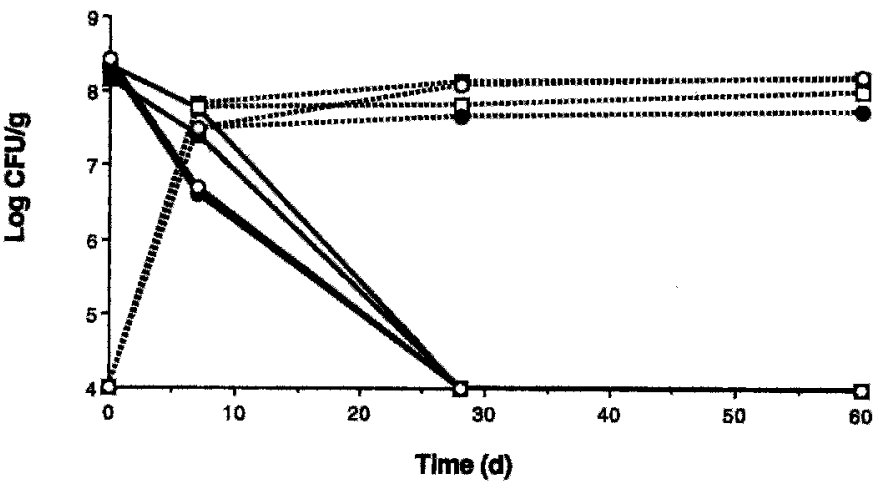

Figure 3. Starter (solid lines) and nonstarter (dotted lines) lactobacilli populations in Swiss cheese during $60 \mathrm{~d}$ of storage as enumerated on esculin cellobiose agar. Cheese was made using L1P1 (ם), L1P2 ( $\square)$, L2P1 (๑), and L2P2 (○) culture combinations. 

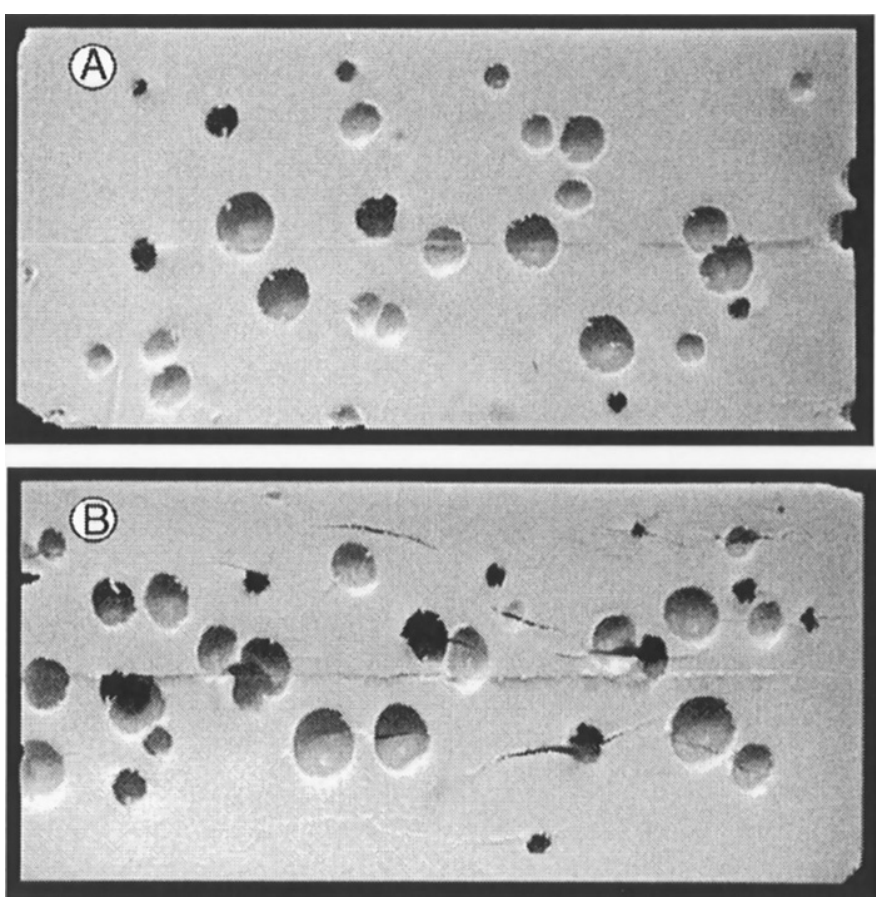

Figure 4. Swiss cheese after $90 \mathrm{~d}$ of storage made using (A) L1P2 and (B) L2P1 starter culture combination. The circle around the letters represents an eye of $17 \mathrm{~mm}$ diameter.

cause of this, indigenous milk enzymes (such as plas$\min$ ) are the main contributors to hydrolysis of $\alpha_{\mathrm{s} 1^{-}}$ casein in Swiss cheese (Fox et al., 1996). However, recent studies (Bastian et al., 1997; Grappin et al., 1999) and our previous observations (unpublished) agree with the observations made during this study, that hydrolysis of intact $\alpha_{\mathrm{s} 1}$-casein and $\beta$-casein occurs at similar rates in Swiss cheese manufactured in the United States. The C. parasitica coagulant that is often used for manufacture of Swiss cheese in the United States has increased activity against $\beta$-casein compared to chymosin (Bogenrief and Olsen, 1995; Bastian et al., 1997).

\section{Microbiological Analysis}

Total lactic acid bacteria counts on MRS agar, were approximately $10^{8} \mathrm{cfu} / \mathrm{g}$ at $\mathrm{d} 1$ for all cheeses. This remained constant for the summer cheese and decreased slightly in the winter cheese to $10^{7} \mathrm{cfu} / \mathrm{g}$. Streptococci (as measured on M17 agar) had an initial population of $10^{8} \mathrm{cfu} / \mathrm{g}$ which then decreased to $10^{7}$ cfu/g by d 7 without any further change during storage. In comté cheese, in which streptococci populations declined slowly over time from $10^{8}$ to $10^{6} \mathrm{cfu} / \mathrm{g}$ during 8 wk of storage and then dropped to $10^{3} \mathrm{cfu} / \mathrm{g}$ by $21 \mathrm{wk}$ (Grappin et al., 1999).
When populations of starter and nonstarter bacteria were examined on esculin cellobiose agar, it was observed that starter L. helveticus colonies were easily distinguished by colony morphology from the nonstarter bacteria. The $L$. helveticus colonies were yellow to light brown, 0.5 to $1.0 \mathrm{~mm}$ diameter and filamentous with no surrounding zone. Lactobacillus helveticus dominated total counts at $\mathrm{d} 1$ (around $10^{8} \mathrm{cfu} / \mathrm{g}$ ) but decreased tenfold to approximately $10^{7} \mathrm{cfu} / \mathrm{g}$ by d 7 (Figure 3). By d 28, numbers of starter lactobacilli had declined to less than $10^{4} \mathrm{cfu} / \mathrm{g}$ (the lowest level discernible on the differential agar because of the large non-starter lactobacilli population). The nonstarter population was less than $10^{4} \mathrm{cfu} / \mathrm{g}$ at $\mathrm{d} 1$, then increased to $10^{8} \mathrm{cfu} / \mathrm{g}$ by $\mathrm{d} 7$, and stayed at that level during further storage. There were no differences in starter and nonstarter numbers between cheeses except that $L$. helveticus culture L2 appeared to decrease in numbers slightly faster than L1. This switch in lactic acid bacteria population may be due to changing environmental conditions in the cheese that allow the initially inhibited contaminant nonstarters to be most prevalent (Crow et al., 1995; Johnson, 2001).

When grown on esculin cellobiose agar, colonies of nonstarter bacteria had different morphologies than L. helveticus. Using API-typing, the most predominant nonstarter lactic acid bacteria were identified as being Lactobacillus rhamnosus and Lactobacillus paracasei. Not all the colony morphologies were the same as that reported by Hunger (1986). For example, Hunger (1986) reported that colonies of $L$. rhamnosus on esculin cellobiose agar have a circular and poorly to strongly eroded colony morphology. However, one of the colony types we identified as $L$. rhamnosus had a circular, undulate (wavy, shallow indentations rather than irregularly notched) morphology, whereas another L. rhamnosus colony had a circular, smooth morphology with a small punctiform in the center of the colony. Also, the API-identified L. paracasei colony had circular, smooth to undulate edges with a punctiform in the center of the colony, and $L$. paracasei had not previously been reported to grow on Esculin cellobiose agar.

\section{Grading}

Individual cultures and the starter culture combinations used during cheese manufacture had significant effects on the cheese grade (Table 4 and 5) and presence of splits (Figure 5) after $90 \mathrm{~d}$ of storage. The strain of propionibacteria used had the most influence on split formation. This was not unexpected because if chemical composition of the cheese (moisture, fat, protein, $\mathrm{pH}$, calcium) is constant, then formation of 
Table 4. Percentage of cheese down-graded because of split defect in cheese based on starter culture used.

\begin{tabular}{lll}
\hline & \multicolumn{2}{c}{ Downgraded cheese } \\
\cline { 2 - 3 } Culture & Summer & Winter \\
\cline { 2 - 3 } L1 & & \\
L2 & 31.7 & 1.6 \\
P1 & 59.4 & 3.1 \\
P2 & 74.0 & 4.2 \\
& 20.0 & 0.0 \\
\hline
\end{tabular}

splits is primarily dependent on continued gas production by the propionibacteria after the cheese has been cooled. Cheese produced using culture P1 had significantly more splits than cheese made using culture P2. There was also a difference in split formation based on which strain of $L$. helveticus was used, with culture L2 producing more splits than culture L1. The cause of this difference between L1 and L2 is not known and does not appear to be a function of extent of proteolysis because there were no gross differences in protein breakdown patterns between L1 and L2. It may be that there is a difference in the small peptides and amino acids that are produced by the starter culture peptidases such that L2 provides greater stimulation of the propionibacteria. A more in-depth analysis of the peptide profiles of Swiss cheese during storage may provide an answer to the observed lactobacilli strain effect on split formation.

There was a large seasonal variation in the amount of splits that formed during storage and when the research had been planned it was expected that there might be a higher incidence of splits in cheese made during the winter when silage was being fed to the cows. Although milk composition was not analyzed, there was some seasonal difference in milk composition because when the same manufacturing procedure was used during winter, there was a $2 \%$ decrease in moisture content in the resultant cheese. The reduced amount of splitting in the winter cheese was attributed to its lower moisture content as compared to the

Table 5. Percentage of cheese down-graded because of split defect for each starter culture combination of lactobacilli L1 or L2 and propionibacteria $\mathrm{P} 1$ or $\mathrm{P} 2$.

\begin{tabular}{lll}
\hline & \multicolumn{2}{c}{ Downgraded cheese } \\
\cline { 2 - 3 } Cultures & Summer & Winter \\
\cline { 2 - 3 } & & \\
L1P1 & 58.3 & 2.1 \\
L1P2 & 13.9 & 0.7 \\
L2P1 & 89.6 & 6.3 \\
L2P2 & 29.2 & $*$ \\
\hline
\end{tabular}

*Not tested.

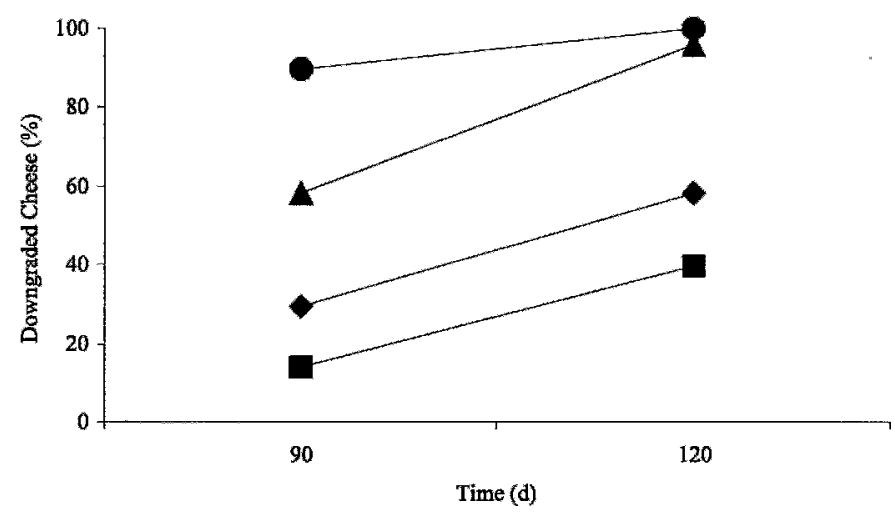

Figure 5. Percentage of summer Swiss cheese downgraded at 90

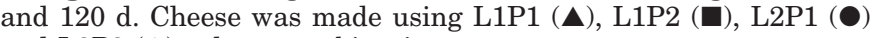
and L2P2 $(\bullet)$ culture combinations.

summer cheese. No evidence was found for splitting of cheese because of the use of silage during winter feeding of the cows. When using P1 culture, $74 \%$ of summer cheese was downgraded after $90 \mathrm{~d}$ storage, because of splits; but only $4 \%$ of the winter cheese was downgraded. In contrast, $20 \%$ of the summer cheese was downgraded when the P2 culture was used, but no splits were observed in the winter cheese. In cheese made with L2 culture, nearly $60 \%$ of summer cheese was downgraded, but only $3 \%$ of winter cheese. When the L1 culture was used, $32 \%$ was downgraded in the summer and $2 \%$ in the winter.

Different starter combinations also affected the probability that cheese would be downgraded. In general, starter combinations followed the same trend as the individual starters with combination L2P1 producing the most splits and combination L1P2 the least. At d 90, 90\% of the summer cheese made using L2P1 combination contained splits (Table 5). In contrast, only $14 \%$ of the L1P2 cheese blocks were downgraded. Even though less than $6 \%$ of the cheese split in the winter, the culture effect was repeatable with L2P1 cheese having the most splits.

Proper selection of both the lactobacilli and propionibacteria starter cultures is an important tool for reducing the prevalence of splits in Swiss cheese. The length of time cheese is held before cutting also influences splits. There were more splits in the cheese as storage time was increased irrespective of the culture used (Figure 6). A total of $48 \%$ of the summer cheese blocks had split at $d 90$ and this increased to $73 \%$ by $\mathrm{d} 120$. The winter cheese did not show any splits at $d$ 60 , while up to $6 \%$ of the cheese had splits at $d 90$ and d 120.

Statistical analysis was performed to see whether there were any analytical measurements of the cheese 
that correlated with the prevalence of splits. Some correlations were statistically significant but the correlation coefficients were small. Apart from moisture content, none of the factors appeared to have a practical application for predicting the occurrence of splits. The cheese-making trials had been designed so that the cheeses would have similar composition, so this was not unexpected. Also, the rate and extent of acid development during cheese making (especially $\mathrm{pH}$ at whey drainage and curd pressing) was tightly controlled to eliminate differences in $\mathrm{pH}$ and calcium content $(0.96 \pm 0.02 \%)$ of the cheese. Thus, all cheeses (within each season) had suitable elasticity necessary for good eye development. Chemical measurements of the cheese such as $\mathrm{pH}$, lactose or D/L-lactate had no correlation with prevalence of splits. In agreement with previous research on Swiss cheese, we found no correlation between prevalence of splits and proteolysis (Hammond and Reinbold, 1965; Park et al., 1967) or hydrolysis of either $\alpha_{\mathrm{s} 1}$-casein or $\beta$-casein (Langsrud and Reinbold, 1973; Grappin et al., 1999).

\section{CONCLUSIONS}

There were no correlations between cheese moisture, $\mathrm{pH}$, fat, protein, calcium, lactose contents, lactate $\mathrm{D} / \mathrm{L}$ ratio, or protein degradation that could be used to predict the amount of splits present in the cheese at $90 \mathrm{~d}$ of storage. Seasonal variation between summer and winter milk resulted in summer cheese having a significantly higher moisture content (37.0 to $37.9 \%$ ) than winter cheese ( 35.0 to $35.5 \%$ ). Proteolysis was significantly higher in summer cheeses, presumably because of the higher moisture content, but there was no correlation between proteolysis and propensity for splits.

Split formation was influenced by both the $L$. helveticus and $P$. freudenreichii ssp. shermanii culture strains used to make Swiss cheese. The L1P2 culture combination produced the lowest incidence of splits for the summer and winter cheeses (14\% and $1 \%$, respectively). There was a sixfold increase in downgraded cheese when the L2P1 culture combination was used.

When a high target moisture level (e.g., 37 to $39 \%$ ) is used for manufacturing Swiss cheese, selection of the L. helveticus and P. freudenreichii ssp. shermanii starter culture becomes important in controlling split defect. Split formation also increases with storage time. If a cheese has a tendency to split, there will be a higher percentage of downgraded cheese the longer it is kept in storage. By selecting the proper combinations, the incidence of splits can be reduced.

\section{ACKNOWLEDGMENTS}

The authors thank Marie Strickland for technical assistance with analysis of protein degradation using capillary electrophoresis.

\section{REFERENCES}

Baer, A. 1995. Influence of casein proteolysis by starter bacteria, rennet and plasmin on the growth of propionibacteria in Swisstype cheese. Lait 75:391-400.

Bastian, E. D., C. G. Lo, and K. M. M. David. 1997. Plasminogen activation in cheese milk: influence in Swiss cheese ripening. J. Dairy Sci. 80:245-251.

Bogenrief, D. D., and N. F. Olsen. 1995. Hydrolysis of $\beta$-casein increases cheddar cheese meltability. Milchwissenschaft. 50:678-682.

Butikofer, U., M. Ruegg, and Y. Ardo. 1993. Determination of nitrogen fractions in cheese: Evaluation of a collaborative study. Lebensm. Wiss.u. Technol. 26:271-275.

Crow, V. L., T. Coolbear, P. K. Gopal, F. G. Martley, L. L. McKay, and H. Riepe. 1995. The role of autolysis of lactic acid bacteria in the ripening of cheese. Int. Dairy J. 5:855-875.

Dasgupta, A. P., and R. R. Hull. 1989. Late blowing of Swiss cheese: Incidence of Clostridium tyrobutyricum in manufacturing milk. Aust. J. Dairy Technol. 44:82-87.

Dave, R. I., D. J. McMahon, C. J. Oberg, and J. R. Broadbent. 2003. Influence of coagulant level on proteolysis and functionality of mozzarella cheese made using direct acidification. J. Dairy Sci. $86: 114-126$

DeMan, J. C., M. Rogosa, and M. E. Sharpe. 1960. A medium for the cultivation of lactobacilli. J. Appl. Bacteriol. 23:130-135.

Fox, P. F., and P. L. H. McSweeny. 1996. Proteolysis in cheese during ripening. Food Rev. Int. 12(4):457-509.

Gagnaire, V., S. Lortal, and J. Leonil. 1998. Free active peptidases are detected in Emmental juice extracted before ripening in the warm room. J. Dairy Res. 65:119-128.

Gautier, M., A. Rouault, P. Sommer, and R. Briandet. 1995. Occurrence of Propionibacterium freudenreichii bacteriophages in Swiss cheese. Appl. Environ. Microbiol. 61:2572-2576.

Grappin, R., E. Beuvier, Y. Bouton, and S. Pochet. 1999. Advances in the biochemistry and microbiology of Swiss-type cheeses. Lait 79:3-22.

Hammond, E. G., and G. W. Reinbold. 1965. Study of the split defect in Swiss cheese. J. Dairy Sci. 48:739-740.

Hettinga, D. H., G. W. Reinbold, and E. R. Vedamuthu. 1974. Split defect of Swiss cheese I. Effect of strain of Propionibacteria and wrapping material. J. Milk Food Technol. 37:322-328.

Hunger, W. 1986. Esculin-Cellobiose agar for the isolation and counting of Lactobacillus acidophilus. Milchwissenschaft 41:283.

Johnson, M. E. 2001. Cheese products. Chapter 11 in Applied Dairy Microbiology 2nd Ed. Marth E. H., J. L. Steele, ed., Marcel Dekker, New York, NY. pp 345-384.

Langsrud, T., and G. W. Reinbold. 1973. Flavor development and microbiology of Swiss cheese-a review III. Ripening and flavor production. J. Milk Food Technol. 36:593-609.

Langsrud, T., and G. W. Reinbold. 1974. Flavor development and microbiology of Swiss cheese-a review IV. Defects. J. Milk Food Technol. 37:26-41.

Marshall, R. T. 1992. Standard methods for the examination of dairy products. 16th ed. American Public Health Association, Washington, DC.

Mocquot, G. 1979. Review of the progress of dairy science: Swisstype cheese. J. Dairy Res. 46:133-160.

Oberg, C. J., B. C. Weimer, L. V. Moyes, R. J. Brown, and G. H. Richardson. 1991. Proteolytic characterization of Lactobacillus delbruekii ssp. bulgaricus strains by the o-phthaldialdehyde test and amino acid analysis. J. Dairy Sci. 74:398-403.

Otte, J., Y. Ardo, B. Weimer, and J. Sorensen. 1999. Capillary electrophoresis used to measure proteolysis in cheese. Pages 10- 
16 in Chemical Methods for Evaluating Proteolysis in Cheese Maturation (Part 2). Bull. 337. Int. Dairy Federation, Brussels, Belgium.

Palma, V., E. G. Hammond, and B. A. Glatz. 1987. Effect of lactobacilli on the properties of Swiss Cheese. J. Dairy Sci. 70:733-737.

Park, H. S., G. W. Reinbold, and E. G. Hammond. 1967. Role of propionibacteria in split defect in Swiss cheese. J. Dairy Sci. 50:820-823.

Piveteau, P., S. Condon, and T. M. Cogan. 1995. Interactions between lactic and propionic acid bacteria. Lait 75:331-343.

Polychroniadou, A., A. Michaelidou, and N. Paschaloudis. 1999. Effect of time, temperature and extraction method on trichloroacetic acid-soluble nitrogen of cheese. Int. Dairy J. 9:559-568.

Reinbold, G. W. 1972. Swiss Cheese Varieties. Pfizer Inc., New York. Salminen, S., and A. von Wright. 1998. Lactic Acid Bacteria. Marcel Dekker, Inc., New York.
Skrzycki, C. 2000. The Regulators: The Hole Truth. Washington Post. Aug. 1, 2000. Page E:01 http://www.washingtonpost.com/ wp-dyn/articles/A13995- 2000Jul31.html.

Steffen, C., P. Eberhard, J. O. Bosset, and M. Ruegg. 1993. Swisstype varieties. Pages $83-110$ in Cheese: Chemistry, Physics and Microbiology. Vol. 2. P. F. Fox, ed. Chapman \& Hall, London, UK

Strickland, M., M. E. Johnson, and J. R. Broadbent. 2001. Qualitative and quantitative analysis of proteins and peptides in milk products by capillary electrophoresis. Electrophoresis $22: 1510-1517$.

Terzaghi, B. E., and W. E. Sandine. 1975. Improved medium for lactic streptococci and their bacteriophages. Appl. Microbiol. 29:807-813.

Thierry, A., D. Salvat-Brunaud, and J. L. Maubois. 1999. Influence of thermophilic lactic acid bacteria strains on propionibacteria growth and lactate consumption in an Emmental juice-like medium. J. Dairy Res. 66:105-113. 